\title{
Components and Methods of Information Culture Development for Students of Engineering Specialization
}

\author{
Naila A. TEPLAYA \\ Dr. habil. (Pedagogics), Associate Professor \\ Professor of the Mathematics and Computer Science Department \\ Institute of Digital Technology and Economics \\ North-Eastern State University \\ 13 Portovaya st., Magadan, 685000, Russian Federation \\ Phone: 7(4132)624632 \\ E-mail: naila69@mail.ru
}

\begin{abstract}
Goal. To describe components of the information culture of a student of engineering specialization and proprietary methodology of their development in the process of level learning. Methodology. Methodological basis of the study comprised of the ideas of the hermeneutic, culturological, systemic, activity approach, as well as research in the knowledge of an information culture. Research methods were specific theoretical methods for scientific presentation of studied problem in the pedagogical field, its analysis, research and confirmation. Analysis of scientific works, educational standards, integrated learning, information component of learning in the systems of general (secondary), professional and additional education was carried out. Results. Engineering (social and legal; modeling and professional; information and communication, creative and research), distinguished components of culture (axiological, imitation, qualification, technological, surveying; regulatory) and methodology of their development.
\end{abstract}

Keywords: field of activity; information culture; component; level learning; method of development.

\section{Introduction}

A multidimensional analysis of scientific research has shown that when acquiring systemic knowledge of a different orientation such as: natural science, information, professional, general technical, and then integrated among themselves, which are based on the principle of "life-long learning" - learning in entire lifetime period - this vision gives the opportunity, in all educational systems during training, to develop information culture of the future engineer (Ministry of Education and Science of the Russian Federation, 2016, Saunders et al., 2015, Gendina, 2015, Gendina, 2016).

A social order for a specialist in the engineer category establishes training requirements in all educational systems. A student of mining and geological specialties with an engineering focus might need:

- act in unusual situations;

- based on the analysis of the geological situation, to predict likely industrial type of mineral;

- using information and communication technologies, resolve professional activities tasks;

- in various landscape and geographic conditions to conduct exploratory work, geological mapping, prospecting and appraisal work;

- draw up projects at different stages of study for geological exploration;

- carry out documentation and design the location of the mine workings;

- to carry out the calculation of reserves of solid mineral deposits and their assessment; 
- choose methods, types and methods of testing their analysis to study the components of the natural environment;

- coordinate and prepare geological tasks for the development of design solutions;

- carry out technical calculations on projects;

- select technical means, apply knowledge of desk exploration, methods of designing field work, and performing engineering calculations;

- conduct simulation, analytical, experimental studies and draw conclusions;

- carry out planning of mining operations, their development and surveying control of mine workings, etc., with ensuring environmental and industrial safety;

- analyze and typify the conditions for the development of mineral deposits for their integrated use;

- compile various surveying projects;

- carry out the necessary geodetic measurements, determine the spatial-geometric position of objects, interpret their results;

- use and study scientific and technical information;

- take part in the implementation of automated production management systems;

- perform laboratory research, interpret its results;

- develop innovative design solutions in the field of professional activity;

- apply in their work special and general purpose software products for field modeling, field exploration, production and processing technologies (Ministry of Education and Science of the Russian Federation, 2016); etc.

Based on the foregoing, the goal in the study of engineering specialties by students, on an integrative basis of subjects, is the formation of competencies in different areas of its activity from course to course.

Information culture of a student in engineering is formed at the level of education: in the system of general (secondary) education - among senior students, in the system of vocational education among specialists, among bachelors, masters, graduate students, and further in the system of additional education - among students of additional education (notable that this idea is based on an analysis of the specifics of the engineer's professional activity, development and scientific and methodological materials of leading scientists on the formation and development of the information culture of engineering students, generalization of advanced pedagogical experience) (Gendina, 2017, Gendina, 2016, Nesterova et al., 2019).

In process of considering the issue of information culture, a theoretical analysis of the research problem was carried out, scientific works of the authors in the field of information cultural studies, as well as in the aspect of the development of the information culture of students of higher educational institutions, were studied. In these works, researchers distinguish various components of information culture, for example, in works in the field of information cultural studies, researchers Kolin and Ursul (2015) believe that the main components of information culture are such components of information culture as the informational qualities of a person, which are formed in him during his life and professional activity; variety of objects of the new information culture material, spiritual and artistic; ways of human activity in the information sphere; new types and forms of information communications that provide the user with increasingly wide opportunities for communication in global information networks.

In the works devoted to the aspects of development of information culture of students of higher educational institutions, authors of the research works identify components of the information culture of different categories of students: 
- for such a category as "Bachelor of Science in Engineering of automobile and road construction", researcher Galynya (2015) identified: motivational-value, cognitive, technological components of information culture.

- in such a category as "a student of a technical university", researcher Gulyakin (2018) identified: praxiological, mental components of the social and information culture.

- for the category "members of cources of engineering major", researchers Kozlov and Undozerova (2019) identified: cognitive, communicative, operational-content, valuereflective components of information culture;

- for the category "students of economic specialization", researcher Gruzdeva (2015) identified such components as social, communicative, modeling, legal, professional components of information culture;

- in a category such as "course member of an educational institution of the Ministry of Internal Affairs of Russia", researcher Nikitina (2017) identified the following components of information culture: cognitive, motivational-value, effective-practical;

- for the category "military cadet", researcher Kozlov (2019) identified such components of information culture as axiological, cognitive-intellectual, communicative-ethical, legal, prognostic, applied, ergonomic;

- for the category "teacher", researcher Lazareva (2016) identified such components of the information culture as information worldview and information competence;

- for the category "future teacher of vocational training", researcher Ataeva (2015) identified such components of information culture as moral-ideological, cognitive-technological, professional-creative; and other works of researchers Vick et al (2015), Gendina (2015, 2016), Nesterova et al (2019), Robert et al (2017), Rohrabou (2012, August 6), etc.

Noting the undeniable value of the available scientific research and the above scientific works, it should be noted that they still establish open nature of the problem of multilevel formation of the information culture of a student in engineering. The need to resolve this problem determines the goals (theoretical justification) and research tasks (analysis of the current state of the problem; identify components of the students' information culture, create methods for their development (which combine pedagogical mechanisms and methodological tools for application) in process of level learning.

\section{Methods}

Methodological basis of the study is:

- ideas of the hermeneutic approach, which helped to build a terminological analysis in the study (to carry out a comparison of concepts);

- ideas of the culturological approach, allowed in the study to determine the essence, structure (components) of the information culture of engineering students taking into account factors of an objective-subjective nature in the context of lifelong learning;

- ideas of a systematic approach, allowed us to present in the study the process of formation of the information culture of students of engineering specialization, as a comprehensive phenomenon - a system with its defining properties, as well as characteristics that determine its quality. This approach makes it possible to coordinate the multi-level process of development the information culture of engineering students (Lazarus et al, 1978).

- ideas of the activity approach, allowed to build the process of forming the information culture of a student of engineering specialization at all levels of the multilevel system from the standpoint of his current activities, based on those information and professional tasks, which he needed to resolve (Gendina, 2016);

- as well as research in the development of an information culture. 
The research methods were represented by theoretical methods for scientific presentation of the studied problem in the pedagogical field, its analysis, research and confirmation. An analysis was made for educational standards, comprehensive training of future engineers and its information component of training in the system of general (secondary) education; in the system of vocational education and further in the system of extended education. A theoretical study of scientific literature was conducted.

\section{Results}

After analyzing the engineering activities, available scientific research on this issue, having studied regulatory documents such as the Federal State Educational Standard of Higher Education in the field of study 05.21.02 Applied Geology (specialist program level) (Ministry of Education and Science of the Russian Federation, 2016) and the Federal State Educational Standard of Higher Education in the field of study 21.05. 04 Mining (specialist program level) (Ministry of Education and Science of the Russian Federation, 2016) - we have identified areas of the engineer's activity (we note that these are areas of the proposed activity) such as: social and legal; modeling and professional; information and communication, creative research. Further, relying on these areas, we divided information culture of the student in engineering into the following components:

- axiological - this component includes determining the civil liability of the future engineer for disseminated information; analysis of available information environment; knowledge of ethical standards; an opinion of what can happen after decisions are made;

- simulation - this component determines competence in the field of modeling, ordering, structuring, systematization, existing and acquired knowledge and data, the disclosure of their meaning by a student of engineering specialization;

- qualification - this component determines for the student of engineering specialization his professionally important competencies necessary to find solutions to the problems of the professional field;

- technological - this component determines the competencies in the field of individual search for professional issues, finding the optimal algorithm using software and various information resources;

- exploratory - this component determines creativity of information activity in various aspects of a student in engineering specialization;

- legal and regulatory - this component determines competencies in the field of information law in a student of an engineering specialization.

In a student of an engineering specialization, development of an information culture begins in a system of pre-university training of an advanced level (general education (secondary)) - these are future students, further it continues in a system of university training (professional education) these are bachelors $\rightarrow$ masters, specialists $\rightarrow$ post-graduate students and applicants for academic degrees; and ends in the continuing education system with the training of course participants (Smirnova et al, 2019).

For such a multi-level formation, in the conditions of continuing education (general (secondary), professional and extended), new proprietary methodology of component development have been worked out, including organizational forms, pedagogical mechanisms, teaching tools for application in the learning process at all levels of the system according to different areas of the future Engineer (social and legal; modeling and professional; information and communication and creative research):

- methodology for the development of the axiological component - is aimed at the formation of competencies in the field of "social"; 
- methodology for the development of the simulation component - is aimed at the formation of competencies in the field of "modeling";

- methodology for the development of the qualification component - is aimed at the formation of competencies in the field of "professional";

- methodology for the development of the technological component - is aimed at the formation of competencies in the field of "information and communication");

- methodology for the development of the regulatory component is aimed at the formation of competencies in the field of "law";

- methodology for the development of the survey component - is aimed at the formation of competencies in the field of "creative research".

The above methods for the development of components, the theory of learning and the teaching methodology are concretized and supplemented, thus allowing in the most logical and highly efficient way to organize a rationally substantiated educational route, with an individual focus, for students in all educational systems, which ensures professional growth for future engineers.

Results obtained in the process of the presented research can be applied in the educational process of any university, as it is determined by the possibility of extending to other areas of professional and additional education that are not related to the engineering specialization.

\section{Conclusion}

It should be noted that:

- author's interpretations of the basic concepts that were formulated in the study, such as: "the regulatory component of the information culture of a student in engineering"; "simulation component of the information culture of a student in engineering"; "axiological component of the information culture of a student in engineering"; "technological component of the information culture of a student in engineering"; "qualification component of the information culture of a student in engineering"; "research component of the information culture of a student in engineering" - expand the conceptual framework of higher education in the field of pedagogy;

- in the conditions of implementation of educational standards of higher professional education (State educational and Federal state educational standards), methods of components formation developed for the educational environment make it possible to organize the gradual formation of an information culture among students under secondary general education programs, specialist programs, undergraduate, graduate, and training of scientific and teaching staff for additional professional programs and vocational training programs;

- with regard to research issues, integrity of the entire phased process of development the information culture of a student at a polytechnic university is achieved at all educational levels (future applicants - pre-university training of an advanced level of schoolchildren (general education (secondary level)); bachelors $\rightarrow$ masters, bachelors and specialists $\rightarrow$ graduate students, applicants for academic degrees - university system of training (vocational education) and course participants (additional education)) by the interconnection of the development of all components of information culture (axiological, simulation, technological, qualification, survey, regulatory) and using proprietary methodology for their formation: methodology for the formation of the axiological component (social field), methodology for the formation of the qualification component (professional field), methodology for the formation of the simulation component (modeling field), methodology for the formation of the technological component (information and communication field), methodology for the formation of the survey component (creative research area), methodology for the formation of the regulatory component (legal area). These methods 
allow the most rational and efficient construction of a logically substantiated individual educational route for students of engineering specialization at all levels of the system, which ensures their professional growth.

\section{References}

Ataeva, E.A. (2015). Model formirovaniya informatsionnoy kultury budushchikh uchiteley informatiki $v$ usloviyakh vuzovskoy podgotovki [A model for the formation of the information culture of future informatics teachers in the context of university training]. Bulletin of the Moscow Institute of Public Administration and Law, 10, 142-148.

Galynya, A.V. (2015). Formirovaniye informatsionnoy kultury u budushchikh bakalavrovinzhenerov avtomobilno-dorozhnogo stroitelstva $v$ protsesse professionalnoy podgotovki: avtoreferat dissertastii [Formation of information culture among future bachelor-engineers of automobile and road construction in the process of training: abstract of thesis]. Yoshkar-Ola.

Gendina, N.I. (2015). Integration of media and information literacy in the structure of information culture of schoolchildren: opportunities and constraints in implementing the MIL idea. Proceedings 12th international scientific conference 'Western Balkan information literacy' June on una river (Bihać, June 18-20, 2015, pp.187-192). Cantonal and University Library Bihac, Limerick Institute of Technology.

Gendina, N.I. (2016). Integrating the Personal Information Culture Concept and the Idea of Media and Information Literacy Offered in the UNESCO Curriculum for Teachers: Experiences of Russia and Uzbekistan. Proceedings 4th European Conference Information Literacy: Key to an Inclusive Society, ECIL 2016 (Prague, Czech Republic, October 10-13, 2016, vol. 676, pp. 543 - 554). Revised Selected Papers. Springer, Cham.

Gendina, N.I. (2016). Integrating the Personal Information Culture Concept and the Idea of Media and Information Literacy offered in the UNESCO Curriculum for Teachers: Experiences of Russia and Uzbekistan. Absctratcs of The fourth European Conference on Information Literacy (ECIL) (Prague, Czech Republic, October 10-13, 2016, p.38). Prague.

Gendina, N.I. (2017). Information Culture and Information Literacy as a Scientific Direction and a Field of Educational Activities in Russia. Pathways into information literacy and communities of practice. Teaching Approaches and Case Studies, 167-202. United Kingdom: Elsevier, Chandos Publishing. DOI: 10.1016/B978-0-08-100673-3.00007-1

Gruzdeva, M.L., Tukenova, N.I. (2015). Sovremennyye kontseptsii formirovaniya informatsionnoy kultury: sravnitelnyy analiz [Modern concepts of the formation of information culture: a comparative analysis]. Bulletin of the University of Minin, 4(12) 13.

Gulyakin, D.V. (2018). Kontseptsiya $i$ pedagogicheskaya sistema formirovaniya sotsialnoinformatsionnoy kultury studentov tekhnicheskogo vuza: dissertatsiya [Concept and pedagogical system of formation of social and informational culture of students of a technical university: thesis]. Grozny.

Kolin, K.K., Ursul, A.D. (2015). Informatsiya $i$ kultura. Vvedeniye $v$ informatsionnuyu kulturologiyu: monografiya [Information and culture. Introduction to Information Culturology: Monograph]. M.: Strategic priorities. 
Kozlov, O.A., Undozerova, A.N. (2019). Teoretiko-metodicheskiye osnovaniya formirovaniya informatsionnoy kultury kursantov inzhenernykh spetsialnostey [Theoretical and methodological foundations of the formation of an information culture of cadets of engineering specialties]. Proceedings of the International scientific-practical conference 'Education Environment for the Information Age - 2019 (EEIA-2019)'. (Moscow, June 4-6, 2019, pp. 727-740). Moscow: FSBSI ISED RAE.

Lazareva, L.I. (2016). Formirovaniye informatsionnoy kultury uchitelya vo vnutrishkolnoy sisteme metodicheskoy raboty s pedagogicheskimi kadrami [Formation of teacher information culture in the intra-school system of methodological work with pedagogical personnel]. Proceedings of the conference 'Actual issues of professional and pedagogical education'. (Ufa, April 14, 2016, pp.46-500). Ufa: Aeterna.

Lazarus, R. S., Launier, R. (1978). Stress-related transactions between person and environment. In: Pervin L.A., Lewis M. (eds) Perspectives in Interactional Psychology. Springer, Boston, MA. DOI: 10.1007/978-1-4613-3997-7_12

Ministry of Education and Science of the Russian Federation. (2016, May 12). Federalnyy gosudarstvennyy obrazovatelnyy standart vysshego obrazovaniya po napravleniyu podgotovki 21.05.02 Prikladnaya geologiya (uroven spetsialiteta) [Federal state educational standard of higher education in the field of training 05.21.02 Applied geology (specialty level)]. http://fgosvo.ru/uploadfiles/fgosvospec/210502.pdf

Ministry of Education and Science of the Russian Federation. (2016, October 17). Federalnyy gosudarstvennyy obrazovatelnyy standart vysshego obrazovaniya po napravleniyu podgotovki 21.05.04 Gornoye delo (uroven spetsialiteta) [Federal state educational standard of higher education in the field of training 05.21.04 Mining (specialty level)]. http://fgosvo.ru/uploadfiles/fgosvospec/210504.pdf

Nesterova, L.V., Lopatinskaya, V.V., Efimova, L.N. et al. (2019). Information culture to information society: a pattern of formation. Proceedings of the International Conference Communicative Strategies of Information Society (CSIS 2018): Advances in Social Science, Education and Humanities Research (Saint Petersburg, October 26-27, 2018, pp.351-354). Atlantis Press

Nikitina, E.O. (2017). Pedagogicheskiye usloviya razvitiya informatsionnoy kultury kursantov obrazovatelnykh organizatsiy MVD Rossii: monografiya [Pedagogical conditions for the development of information culture of cadets of educational organizations of the Ministry of Internal Affairs of Russia: monograph]. M.: Publishing house of Moscow University of the Ministry of Internal Affairs of the Russian Federation.

Robert, I.V., Mukhametzyanov, I.S., Arinushkina, A.A. et al. (2017). Forecast of the development $\begin{array}{lllll}\text { of education } & \text { informatization. } & \text { Espacios, } & 38(40), & 32 .\end{array}$ https://www.revistaespacios.com/a17v38n40/a17v38n40p32.pdf

Rorabaugh, P. (2012, August 6). Occupy the Digital: Critical Pedagogy and New Media. Hybrid Pedagogy. https://hybridpedagogy.org/occupy-the-digital-critical-pedagogy-and-new-media/

Saunders, L., Kurbanoglu, S., Boustany, J. et al. (2015). Information Behaviors and Information Literacy Skills of LIS Students: An International Perspective. Journal of Education for Library and Information Science, 56, 80-100. DOI: 10.12783/issn.2328-2967/56/S1/ 
III International Theoretical and Practical Conference "The Crossroads of the North and the East (Methodologies and

Practices of Regional Development)"

Smirnova, Z.V., Golubeva, O.V., Chaykina, Z.V. et al. (2019). Professional training in higher education: technological aspect. International Journal of Innovative Technology and Exploring Engineering, 8(12), 3505-3509. https://1ibrary.net/document/8ydpxejyprofessional-training-in-higher-education-technological-aspect.html

Vick, T.E., Nagano, M.S., Popadiuk, S. (2015). Information culture and its influences in knowledge creation: Evidence from university teams engaged in collaborative innovation projects. International Journal of Information Management, 35(3), 292-298. DOI: 10.1016/j.ijinfomgt.2015.01.010 